ISSN (Online) 2710-3315

https://doi.org/10.20535/EHS.2021.233242

УДК 628.46:004.93'1

\title{
РОЗРОБКА ІНФОРМАЦИЙНОЇ СИСТЕМИ ДЛЯ ПЕРЕРОБКИ ТВЕРДИХ ПОБУТОВИХ ВІДХОДІВ
}

\author{
О.В. Клановець, В.І. Бендюг \\ Національний технічний університет України \\ "Киїський політехнічний інститут імені Ігоря Сікорського" \\ пр. Перемоги, 37, Київ, 03056, Україна \\ e-mail: alex.klanovets@gmail.com
}

У всьому світі рівень продукування відходів зростає. У 2016 році міста світу утворили 2,01 млрд тонн твердих побутових відходів, що становило в середньому 0,74 кілограма на людину на день, проте діапазон є більш широким - від 0,11 до 4,54 кг на людину [1-2]. Очікується, що при швидкому прирості населення та урбанізації щорічне утворення відходів збільшиться на 70\% від рівня 2016 року до 3,40 млрд тонн у 2050.

В даний час у розвинутих країнах значна кількість побутових відходів збирається i переробляється не міськими комунальними службами, а приватними підприємствами, які також мають справу з промисловими відходами.

У вартісному вираженні обсяг ринку муніципальних відходів у країнах, що розвиваються оцінюється приблизно у 120 млрд дол. Найбільше значення мають ринки США (46,5 млрд дол.), Європи (країни Євросоюзу разом з Норвегією і Швейцарією, близько 36 млрд дол.) і Японії (близько 30,5 млрд дол.). У світовій практиці до цього часу переважну кількість твердих побутових відходів все ще продовжують вивозити на звалища (полігони): у країнах пост радянського простору на звалища вивозять 97\% відходів, у США - 73\%, у Великобританії $90 \%$, у Німеччині - 70\%, у Швейцарії - 25\%, в Японії - близько 30\% [3].

Правильне поводження з відходами є надзвичайно важливим для побудови стійких і придатних для життя міст, але це залишається проблемою для багатьох країн та міст, що розвиваються. Ефективне поводження з відходами є дорогим, часто воно складає 20-50\% муніципальних бюджетів [1]. Для функціонування цієї основної комунальної служби потрібні інтегровані системи, які є ефективними, стійкими та соціально підтримуваними.

Тож головним завданням $є$ розробка нових та оптимізація існуючих підходів до управління утворенням відходів, їх утилізації та переробки, зокрема із залученням IT-технологій i створення спеціалізованих інформаційних систем. В даній роботі розглядатимуться існуючі рішення та технології серед інформаційних систем, які виконують поставлене завдання, а також пропонується варіант системи для автоматизації процесу збору та сортування сміття в містах із застосуванням технологій машинного зору.

Розвиток ринку цифрових рішень в галузі переробки твердих побутових відходів йде за чотирма основними напрямками [4]: виробництво смарт-систем для збору відходів (так звані «розумні контейнери»); оптимізація логістичних ланцюжків і оснащення автопарку спеціалізованим програмним забезпеченням і датчиками («розумні збирачі сміття»); виробництво i впровадження інтелектуальних систем переробки i утилізації твердих 
побутових відходів; а також розробка і застосування хмарних технологій і призначених для користувача інтерфейсів.

Станом на жовтень 2018 року найбільша кількість смарт-технологій і обладнання для управління переробкою твердих побутових відходів розробляється в країнах Західної Європи і Північної Америки [4]. Крім «розумних» контейнерів і сміттєзбирачів, до них також відносяться роботизовані системи для сортування твердих побутових відходів, спеціалізовані мобільні додатки, системи обліку і аналітики, спеціалізовані ERP-системи, програмне забезпечення та ін.

Серед основних тенденцій ринку технологій цифрової трансформації в галузі можна виділити розвиток інтернету речей (Internet of Things, IoT), концепції «Розумне місто» («Smart City»), а також бізнес-моделей «Платформа як послуга» (Platform as a Service, онлайн-сервіси 3 можливістю вибору послуг виходячи з індивідуальних вимог) $\mathrm{i}$ «Програмне забезпечення як послуга» (Software as a Service, набір функцій або програмних рішень, якими може оснащуватися технологічне обладнання).

Основні існуючі проблеми індустрії переробки відходів - нестача (або повна відсутність) інформації про кількість твердих побутових відходів, які були зібрані/переробляються, нерозвиненість інфраструктури і сфери послуг в окремих країнах і регіонах, стабільне зростання транспортних витрат компаній, низький рівень технологічної оснащеності підприємств та ін. Прикладом підходу до вирішення даних проблем є загальнодержавна програма по управлінню переробки відходів Swachh Bharat Mission, яку представила влада Індії у 2014 році [5]. Ключовими технологіями, які мають бути реалізовані в рамках даної програми є:

1) Контейнери для сміття зі спеціальними сенсорами для виявлення стану сміттєзбірників, якщо вони порожні або заповнені, щоб відповідно налаштувати графік збору відходів та заощадити витрати.

2) Технологія GPS для маршрутизації вантажівок для збору відходів з метою оптимізації ефективності збору та забезпечення того, щоб підрядники скидали відходи у відведених місцях.

3) Сортування відходів за допомогою сенсорних технологій та спектрального аналізу. Сенсорні технології здатні розпізнавати матеріали на основі їх видимого спектру або кольору за допомогою інфрачервоного / ультрафіолетового спектрів або на основі їх конкретних та унікальних спектральних властивостей відбитого світла, чи атомної щільності, провідності / проникності тощо.

4) Використання технологій «Smart City» та моніторинг ефективності міських підсистем за допомогою цифрових технологій та аналізу великих даних.

Серед існуючих продуктів та систем на ринку також виділимо наступні:

- ERP-система AMCS Platform. Це корпоративна платформа Software as a Service (SaaS), яка дозволяє компаніям, що займаються переробкою твердих побутових відходів, працювати ефективніше за рахунок автоматизації розрахунків, планування, ведення аналітики, інтелектуальних інструментів прогнозування, включаючи управління вироблення відходів. Платформа AMCS інтегрує рішення по управлінню підприємством, інтелектуальній оптимізації діяльності, аналітиці [6].

- RECICLOS [7] - це заохочувальна return-and-reward система, яка за допомогою мобільних технологій пропонує стійкі та соціальні стимули для винагороди за екологічні зобов'язання громадян, які як вдома, так і за межами викидають банки та пластикові пляшки у спеціально призначені сміттєві контейнери або жовті контейнери, котрі після викидання надають QR-код для отримання винагороди (рис. 1a). Проект розпочато з метою розробки 
за допомогою мобільних технологій та системи винагородження моделі переробки банок та пластикових пляшок з напоями у жовтих контейнерах, яка широко використовується в Іспанії вже понад 20 років. Заохочення до правильного поводження з відходами надаються, наприклад, у вигляді знижок на громадський транспорт.

- Продукція компанії Zenrobotics [8], а саме робототехніка для сканування та сортування відходів, у тому числі будівельних. Приклад продукту - сортувальний робот Fast Picker (рис. 1б). ZenRobotics Fast Picker працює на основі ZenbrAIn, програмного забезпечення для штучного інтелекту, яке аналізує дані та керує роботами. ZenbrAIn постійно навчається, дозволяючи операторам швидко реагувати на зміни в потоці відходів. Як результат, список відходів, які оброблюються ZenRobotics Fast Picker можна розширювати під потреби клієнта. Особливості Fast Picker включають:

- сортування необмеженої кількості відходів;

- 4000 вилучень відходів на годину;

- максимальна вага предмета 1 кілограм;

- максимальний розмір об'єкта 400 міліметрів;

- гібридне сортування за допомогою позитивного та негативного сортування одночасно;

- замінює ручне сортування;

- підвищує показники відновлення продукту та чистоти;

- проста установка на існуючих підприємствах по переробці відходів (Materials Recovery Facility).
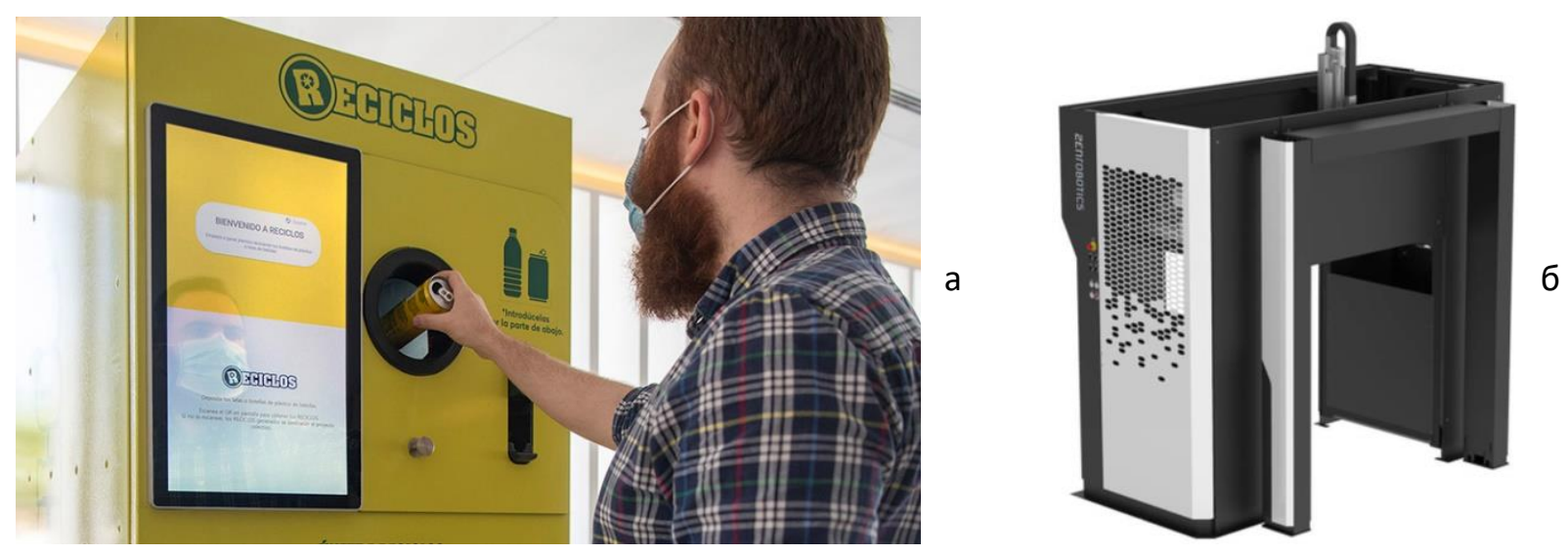

Рисунок 1. Приклади реалізації систем сортування сміття: a) RECICLOS; б) ZenRobotics Fast Picker

В даній роботі пропонується створити систему, яка представлятиме собою мережу автоматизованих пунктів сортування твердих побутових відходів в рамках міста. Дана інфраструктура має намір оптимізувати логістику підприємств переробки твердих побутових відходів, надавати їм точні відомості про кількість сміття, автоматизувати і пришвидшити сортування, при цьому роблячи його більш якісним.

По всіх районах міста пропонується рівномірно розташувати пункти у межах пішої доступності жителів для викидання відходів. Пункти в районах будуть утворювати кластери 3 центром управління та диспетчеризації. Дані центри будуть слідкувати за станом кожного свого пункту. 
Пункт прийому сміття представлятиме собою роботизовану систему, яка використовує технології комп'ютерного зору для класифікації матеріалу та габаритів відходів, а також сенсорами, які визначають ступінь заповнення резервуарів для відходів даного пункту. Пункт надсилає інформацію про кількість зібраного сміття в центр управління, де дана інформація оброблюється та використовується для планування оптимального маршруту сміттєзбираючого транспорту, що значно знижуватиме вартість логістики. Окрім ступеню заповнення, пункт також надсилатиме службову інформацію про можливі помилки, несправності і т. д. Диспетчер центру управління проводить моніторинг стану пунктів $\mathrm{i}$ приймає відповідні дії у аварійних або інших випадках.

В центах управління відбувається агрегування та аналіз інформації, отриманої з пунктів. Завдяки аналізу часових рядів значень заповнення пунктів, система матиме змогу виконувати прогноз використання пунктів в майбутньому за допомогою методів машинного навчання, що дає змогу наперед планувати ресурси та діяльність підприємств 3 переробки твердих побутових відходів.

Неодмінною перевагою даної системи є те, що вона є гнучкою і може підлаштовуватись під потенційно будь-які типи відходів завдяки здатності системи до навчання. Тобто, кластери таких пунктів можуть працювати для збору побутового сміття мешканців міста, а також для збору промислових відходів, металолому тощо.

Можливе додаткове введення системи заохочувань при використанні мешканцями міст даних пунктів сортування. Система заохочувань може бути подібною до розглянутої вище системи RECICLOS.

Опишемо деталі проектування та реалізації.

Пункт сортування є роботизованою системою, яка оснащена маніпулятором, котрий здатний переміщуватись по трьом осям. Також в складі пункту $є$ конвеєр, полотно якого $є$ рухомим і здатне рівномірно та розріджено розподіляти відходи по всій площі полотна для більш точної класифікації та захвату відповідного сміття маніпулятором. Над лінією конвеєра розташовано камеру для сканування відходів та LED-освітлення. Звичайному користувачу доступний лише спеціальний отвір для подачі відходів. Після викидання сміття, перед попаданням його на конвеєр необхідно додатково розкрити/розірвати пакування, яке використовувалось для поданих на вхід відходів. Даний процес $є$ автоматичним. Самі резервуари та внутрішні механізми системи є захищеними від несанкціонованого доступу. У разі спроби пошкодити систему пункт відправлятиме відповідний сигнал до локального центру управління.

Виконання необхідних обчислень, управління периферією та класифікація буде виконуватись спеціальним мікрокомп'ютером. В якості варіанту мікрокомп'ютера можна використати Raspberry Pi 3 Model A+ та більш нових версій. Як вже було сказано, задача мікрокомп'ютера - управління сенсорами, відправка повідомлень до центру управління, обчислення класів та положень відходів на конвеєрі і відповідне переміщення маніпулятора.

Передача повідомлень від пунктів обробки буде здійснюватися за допомогою спеціалізованих протоколів. Варіантом протоколу може слугувати протокол MQTT (message queuing telemetry transport) [9]. Даний протокол $є$ мережевим протоколом прикладного рівня в моделі OSI/ISO, зазвичай працює над стеком TCP/IP. Використовується у сфері Інтернету речей, застосовується для обміну даними (повідомленнями) між пристроями мережі за принципом publish-subscribe, тобто пристрої, які хочуть передати повідомлення (publishers або видавці), відправляють його серверу (брокеру), пристрої які хочуть отримати повідомлення (subscribers або підписники), також підключаються до брокера і отримують повідомлення від нього (рис 2) [10]. 
Основна ідея протоколу - перенесення частини системи, яка потребує значної кількості ресурсів, на елемент, у якого наявні дані ресурси, що дозволяє іншим учасникам системи значно економити власні ресурси. Основне призначення - робота $з$ технологіями телеметрії від різних датчиків, пристроїв. Протокол дозволяє даним пристроям виходити на зв'язок та обмінюватись інформацією, при цьому витрачаючи якомога менше ресурсів, що і стало приводом для розгляду його використання.

Для розпізнавання об’єктів (відходів) на зображенні 3 камери у реальному часі використовується згорткова нейронна мережа (Convolutional neural network). Даний тип нейронних мереж гарно працює в задачах машинного зору, надаючи високий рівень точності розпізнавання, так як використовує спеціальні математичні операції - згортки (convolutions), завдяки яким можна виділяти з зображення важливі для класифікації об'єктів ознаки (рис. 3).

Така мережа має бути попередньо спроектована та навчена на відповідному наборі даних (фотографій різних типів відходів із зазначеними відповідними їм класами). Для підбору архітектурних гіперпараметрів моделі та іiі навчання існують різні підходи. Загалом, увесь наявний набір даних ділиться на навчальний, валідаційний (якщо розмір вибірки дозволяє, інакше використовується підхід крос-валідації) та тестовий. Навчальний набір використовується для безпосереднього навчання мережі, валідаційний - для підбору структурних параметрів (кількість шарів, їх типи тощо). На тестовому перевіряється остаточна точність мережі. Замість того, щоб підбирати архітектуру всієї мережі з нуля, можна скористатись технікою transfer learning, завдяки якій можна модифікувати вже навчені на певній загальній задачі мережі під специфічне застосування.

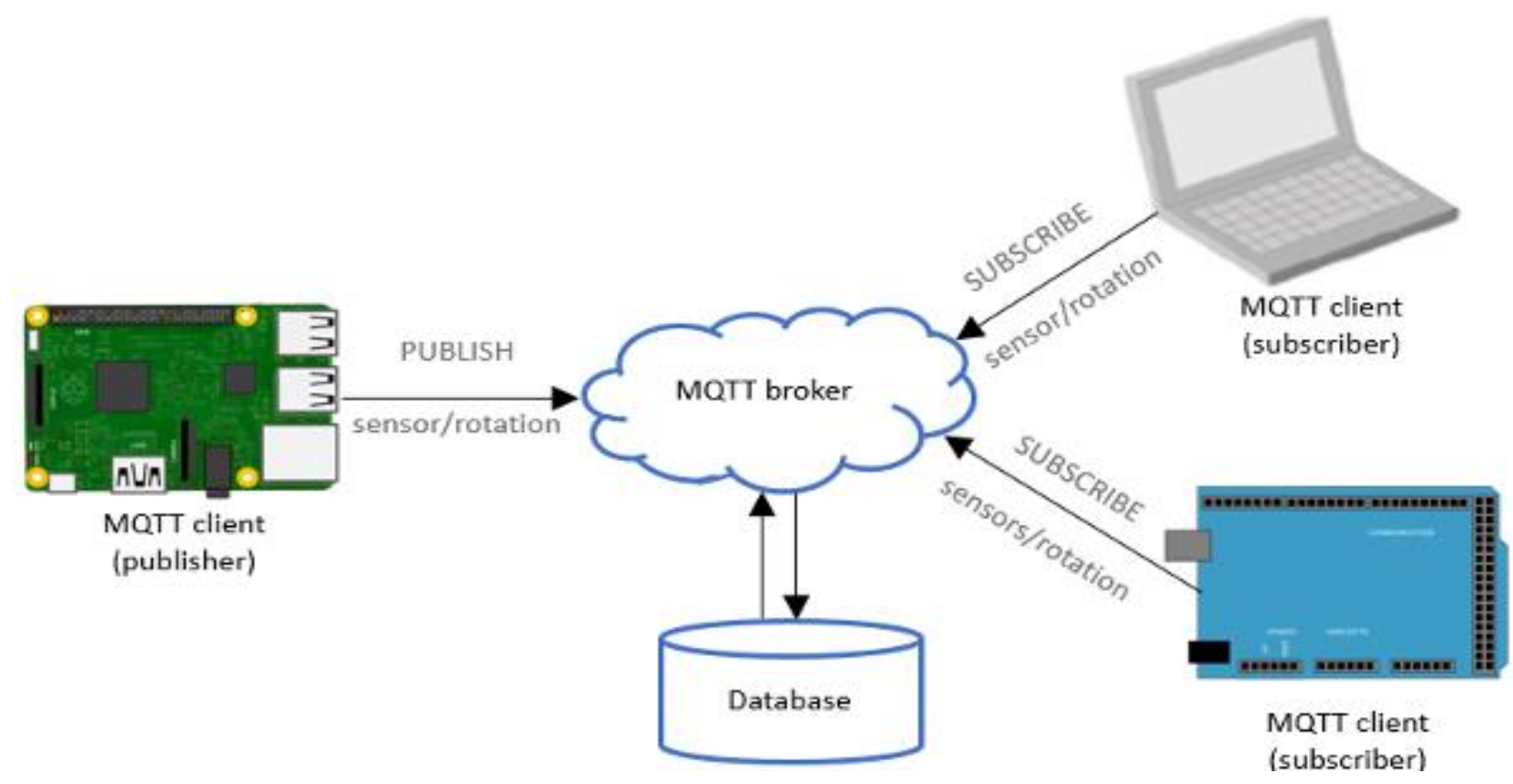

Рисунок 2. Схема роботи протоколу МQTT

Розробку та навчання самої моделі можна здійснити за допомогою інструментів Tensorflow [11] та Keras [12]. Tensorflow - платформа та екосистема 3 інструментів для створення різноманітних моделей машинного навчання, включаючи глибокі нейронні мережі, та їх 
навчання. Keras - високорівневий API для простої і швидкої побудови моделей, вбудований в Tensorflow. Розгортання моделі на мікрокомп’ютері можна виконати за допомогою Tensorflow Lite, так як саме цей інструмент призначений для розробки та розгортання моделей машинного навчання на мобільних та вбудованих пристроях.



\section{Рисунок 3. Приклад архітектури згорткової нейронної мережі}

Аналіз поточної ситуації в світі щодо кількості продукованих відходів лише підтверджує масштабність і важливість проблеми на сьогоднішній день. Динаміка росту населення, споживання продуктів і ведення господарства, збільшення міського населення - лише деякі чинники зростання кількості відходів.

Світове товариство серйозно ставиться до даної проблеми, і тому кожен рік пропонується все більша кількість інноваційних проектів по оптимізації управління переробкою твердих побутових відходів. В даній роботі саме розглядалися приклади інформаційних систем, які вже впроваджуються в світі та допомагають у вирішенні питання забруднення та повторного використання вторсировини. Головними напрямками розвитку інформаційних технологій, як було відзначено, є виробництво смарт-систем для збору відходів, оптимізація логістичних ланцюжків і оснащення автопарку спеціалізованим програмним забезпеченням і датчиками, виробництво i впровадження інтелектуальних систем переробки i утилізації твердих побутових відходів. Набирають популярності інтелектуальні методи в сортуванні, використання технологій Інтернету речей та Розумного міста.

Був описаний новий підхід до вирішення проблеми із застосуванням передових технологій в сфері комп'ютерного зору для автоматизації сортування відходів та розробки ефективної інфраструктури з метою оптимізації витрат на збір, вивезення та переробку твердих побутових відходів. 


\section{Література:}

1. Solid Waste Management [Електронний pecypc] // - 2019. - Режим доступу: https://www.worldbank.org/en/topic/urbandevelopment/brief/solid-waste-management

2. Trends in Solid Waste Management [Електронний ресурс] // - Режим доступу: https://datatopics.worldbank.org/what-a-waste/trends_in_solid_waste_management.html

3. Технологія переробки побутових відходів та відходів сільського господарства: курс лекцій для здобувачів вищої освіти ступеня «бакалавр» спеціальності 162 «Біотехнології та біоінженерія» / О. І. Каратєєва. - Миколаїв : МНАУ, 2018. - 190 с.

4. How to transform waste management using ICT to enable Swachh Bharat Mission [Електронний ресурс] // $\quad$ - $2015 . \quad$ - 2 Режим доступу: https://economictimes.indiatimes.com/news/science/how-to-transform-waste-management-usingict-to-enable-swachh-bharat-mission/articleshow/47957702.cms?from $=\mathrm{mdr}$

5. Технологии в переработке мусора [Електронний ресурс] - Режим доступу: https://www.tadviser.ru/index.php/Статья:Технологии_в_переработке_мусора

6. AMCS Platform - a unique enterprise-grade software platform [Електронний ресурс] Режим доступу: https://www.amcsgroup.com/solutions/amcs-platform/
7. RECICLOS
[Електронний
pecypc]
Режим
доступу:

https://www.thecircularlab.com/en/explore/reciclos/

8. Zenrobotics [Електронний ресурс] - Режим доступу: https://zenrobotics.com/

9. MQTT Version 3.1.1. OASIS Standard [Електронний ресурс] // - 29 жовтня 2014. - Режим доступу: https://docs.oasis-open.org/mqtt/mqtt/v3.1.1/os/mqtt-v3.1.1-os.html

10. Publish MQTT Messages and Subscribe to Message Topics - MATLAB \& Simulink [Електроннй ресурс] - Режим доступу: https://www.mathworks.com/help/supportpkg/raspberrypi/ref/publish-and-subscribe-to-mqttmessages.html

11. Tensorflow [Електронний ресурс] - Режим доступу: https://www.tensorflow.org/

12. Keras [Електронний ресурс] - Режим доступу: https://keras.io/ 